University of Tulsa College of Law

TU Law Digital Commons

Articles, Chapters in Books and Other Contributions to Scholarly Works

2013

'Ah, you publishing scoundrel!' A Hauntological Reading of Privacy, Moral Rights, and the Fair Use of Unpublished Works

Robert Spoo

Follow this and additional works at: http://digitalcommons.law.utulsa.edu/fac_pub

Part of the Intellectual Property Commons

Recommended Citation

Law \& Literature, Vol. 25, No. 1 (Spring 2013): 85-102.

This Article is brought to you for free and open access by TU Law Digital Commons. It has been accepted for inclusion in Articles, Chapters in Books and Other Contributions to Scholarly Works by an authorized administrator of TU Law Digital Commons. For more information, please contact daniel-bell@utulsa.edu. 
of great concern, but it does not require substantial modifications to the arguments being made in this essay. Censorship remains a product of both governmental and private forces. The term "forebear of God-like concentrated power," employed directly above this note, allows for the possibility that concentrated capital has become the patron.

go. For instance, Lawrence Lessig argues that the law of cyberspace (law that includes nor only stateenforced decrees, but also computer coding that limits the practical choices available to users) will be constitutive of the form of human life itself. He argues that we should think about what kind of human life we would like to see constituted and then make our societal decisions concerning the law of cyberspace accordingly. See Lawrence Lessig, Code: Version 2.0 (New York: Perseus, 2006). The present essay agrees with Lessig's analysis but cautions that the kind of societal decisions Lessig would like to see made (which seem to involve something like the "democratization of creativity" being discussed here) will themselves be constituted by decisions concerning reform of inheritance law. If that first, more politically taxing set of decisions is disregarded, forebear desire, empowered by current inheritance law, will no doubt veto the kinds of cyberspace-law decisions Lessig would approve.

\section{"Ah, you publishing scoundrel!": A Hauntological Reading of Privacy, Moral Rights, and the Fair Use of Unpublished Works}

Robert Spoo

\begin{abstract}
The doctrine of fair use, as applied to unpublished works, has long been haunted by the specters of privacy and moral rights, a haunting that reached a crisis point in the 1980s when certain court decisions appeared to be evolving a per se rule against the fair use of unpublished works. This chilly season was only partly warmed in 1992 when Congress amended the Copyright Act to clarify that the unpublished nature of a work may not itself bar a finding of fair use. In the years since, no legal case has fully tested the force of Congress's amendment in the context of scholarly quotation. Publishers and editors in the humanities remain fearful that quotation from unpublished documents will trigger liability or threats of it. By way of analytical exorcism, this essay focuses on the fair use of unpublished works by authors who have since died, in order to make vixid the general problem of allowing privacy and moral rights to haunt the fair use doctrine. As a way of probing these poltergeists more richly, the essay discusses ghost stories by Henry James that anticipate current preoccupations with authorial privacy and moral rights. The essay concludes that we should banish these ghosts in favor of the productive uncanniness of transformative fair use.
\end{abstract}

Keywords: fair use / unpublished works / copyright / transformative / transformativeness / privacy / privacy rights / moral rights / right of frst publication / authors / deceased authors / law and literature / Henry James / James Joyce / James Joyce Estate

A specter is haunting the doctrine of fair use, the specter of privacy and moral rights. In the United States, fair use is defined as a limitation on the exclusive rights of copyright owners. ${ }^{1}$ Notoriously indeterminate but

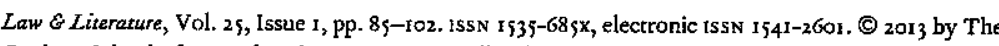
Cardozo School of Law of Yeshiva University. All rights reserved. Please direct all requests for permission to photocopy or reproduce article content through the University of California Press's Rights and Permissions website, at http://wWw.ucpressjournals.com/reprintinfo.asp. DOI: 10.1525/lal.2013.25.1.85. 
a potent privilege nonetheless, fair use has operated most intelligibly when it has been applied by courts to challenged uses of published works. Unpublished works - the focus of this essay--have posed difficulties for fair use analysis. The four fair use factors, when tallied and balanced in favor of a defendant, excuse the unauthorized use of a protected work, particularly when the use is deemed "transformative," that is, when it "adds something new, with a further purpose or different character, altering the [çopyrighted work] with new expression, meaning, or message."2 Transformativeness can offset a use's commercial character, so that fair use is not necessarily confined to academic and other noncommercial purposes, and a finding of fair use is not always a reward for self-denial.

Transformativeness introduces the principle of irony and an element of the uncanny into copyright doctrine. A nontransformative use operates on a literal plane; it reproduces the work in a familiar context that usurps or overlaps the copyright owner's existing or potential markets. In contrast, when the artist Jeff Koons embedded a portion of a fashion photograph in a billboard-size canvas containing other fragments of advertising culture, he uncannily, and fairly, used a protected work to transpose aesthetic purposes and confound consumer expectations. ${ }^{3}$ Transformative fair use is commercially ironic in that it says one thing but means it in a different market. It is uncanny because it offers the familiar in an unfamiliar frame, a doubling with a difference, as when Sigmund Freud unexpectedly glimpsed himself in a mirror and disliked the strange elderly man he saw there. ${ }^{4}$ It is no wonder that parody, a vivid kind of transformativeness, has become almost iconic for advocates of fair use; the ironic, frame-changing nature of parody marks it, for many, as the subversive use par excellence.

Most fair use cases involve published works - the factual matrix in which the doctrine of transformativeness has largely taken shape. Fair use of unpublished works remains a comparatively uncharted region of American law. In the 1980 , Harper $\mathcal{E}$ Row, Publishers, Inc. v. Nation Enterprises, ${ }^{5}$ Salinger $v$. Random House, Inc., ${ }^{6}$ and other court decisions appeared to be evolving a brusque, per se rule that there could be no fair use of unpublished works, even though the uses those courts considered included news reporting and serious biography. In Salinger, the Second Circuit, ruling against a biographer who had quoted from and paraphrased personal letters of J. D. Salinger held in public archives, stated that unpublished works "normally enjoy complete protection against copying any protected expression."7 Two years later, the same court remarked, "Where use is made of materials of an 'unpublished nature,' the second fair use factor [the nature of the work] has yet to be applied in favor of an infringer." almost timorous deference of this language, its categorical awe for works that had not been distributed in copies to the public, suggested to some observers that concern for something other than ordinary market harm was driving these decisions.?

The chilly season that these cases ushered in was only partly warmed in I992 when Congress, responding to the concerns of historians and biographers, ${ }^{10}$ amended Section 107 of the 1976 Copyright Act by adding an important clarification: "The fact that a work is unpublished shall not itself bar a finding of fair use if such finding is made upon consideration of all the [fair use] factors." 11 The legislature's Spartan language went to the core of the problem that had been brewing in the case law. The phrase "shall not itself bar" addressed the gathering per se rule against fair use of unpublished works; the reminder that courts should consider "all of the above factors" stressed the necessity of balancing all the circumstances of a given use. And yet in the years since Congress added this critical language, there have been few significant cases involving fair use of unpublished works, and no case has fully tested the force of Congress's amendment in the context of scholarly quotation. ${ }^{12}$ Publishers and editors in the humanities remain fearful that even brief, critical quotation from unpublished documents will trigger liability; they often discourage such quotation or require permissions from sometimes intractable or untraceable copyright holders. My experience as a copyright advisor to several academic journals in the United States suggests that, even when editors are aware of the 1992 amendment, they feel reluctant to act on it, caught in the grip of the traumas inflicted by Salinger and other pre-1992 decisions. ${ }^{13}$ The 1992 amendment exists not as a dead letter, but rather as a dormant one in the contexts that this essay particularly, though not exclusively, addresses.

As a result, publishing in the humanities is trepid and embattled, even when scholars try to quote from the copyrighted works of deceased authors. Journal editors and other copyright gatekeepers anguish over quotations from personal letters, diaries, and manuscripts. ${ }^{14}$ University presses not infrequently adhere to parsimonious word counts and rigid permissions policies. ${ }^{15}$ Academics continue to practice what I have elsewhere referred to as the timid art of design-around scholarship, trimming 
their quotations to the bone, offering bloated and bloodless paraphrase, and where published works are concerned, substituting public-domain editions for better, copyrighted ones. ${ }^{16}$ Scholars who design around copyrighted materials and publishers that enforce stringent quotation policies are avoiding a productive confrontation with fair use and its fundamental purposes.

In this essay, I argue that this institutional timidity has been exacerbated by certain specters that continue to haunt the fair use doctrine: personal privacy and the old rule that authors have the exclusive choice of when and where to publish their writings initially. The first specter involves a misplaced solicitude for deceased writers' or their families' right to be let alone. The second imports into copyright law what is at best an analytical redundancy and at worst a species of moral right that clouds fair use thinking. Both were emboldened by Salinger and similar cases. Like all ghosts, these visitants are extraneous horrors, menacing copyright law from unrelated regions of law and morality; they have no place, or only a very limited one, in a proper understanding of fair use. Ghosts are dysfunctional fragments of the past, carried forward into the present by unexorcised fears. I contend that these phantoms must be banished by courts, scholars, and publishers before the benefits of fair use can be fully realized.

At the outset, I want to make it clear that I am not assailing legal protections for personal privacy. The privacy torts and other sources for preserving the right to be let alone have never been more important than they are today, when so many ordinary activities-surfing the Web, buying groceries, strolling along a public sidewalk—can result in an unwitting surrender to surveillance. My point is that copyright law and fair use should not be made additional instruments for policing privacy. When that happens, the delicate mechanism of fair use becomes unbalanced, and users' rights may be sacrificed to nebulous, noneconomic concerns. Mixing fair use and privacy has never made much sense anyway. Copyright law permits the facts and ideas contained within protected expression to be revealed without permission; and even that expression may be freely used once the copyright has expired. ${ }^{17}$ Adding privacy to the fair use calculus thus introduces a potent incoherency, allowing an author's secrets to be told as long as they are told in an alien voice. Or, if a user does wish to report the author's actual unpublished expression, the only really safe way is to wait until the copyright, rather than the author, has expired-a type of restraint at odds with the rest of American privacy law, which largely withdraws its protections after an individual dies. ${ }^{18}$

In this essay, I place special emphasis on the fair use of unpublished works created by authors who have since died. In stressing this specific though common scenario, I do not mean to suggest that the importation of privacy concerns into fair use analysis is any more justified when authors are still living. To the contrary, I focus on postmortem use as an a fortiori case, a way of making vivid the general problem of allowing privacy and moral rights to haunt the fair use doctrine. To probe this haunting more richly, I'd like to discuss a story by Henry James that captures some of the preoccupations with authorial privacy and moral rights that inform the current climate of scholarly quotation and that continue to skew the functioning of fair use. James, who late in life made a prophylactic bonfire of his accumulated manuscripts, notebooks, and letters, ${ }^{19}$ wrote during a time when cheap publishing, popular journalism, and celebrity culture were rapidly eroding the ability of authors to conceal their private lives and control their public images, even as copyright law and nascent privacy rights gave them hope of keeping inquiring minds at bay. James's fictions of authorial privacy are watermarked by the rising tide of commercialized gossip and compensatory legal regimes. That tide has continued to wash, and to warp, our present doctrine of fair use.

Among James's psychological and moral chillers, which notably include The Turn of the Screw and The Jolly Corner, is a very short story called "The Real Right Thing" (1899). It opens with the recent untimely death of a celebrated author, Ashton Doyne, and the plight of his grieving widow. The Doynes' marriage had lacked something. James, in his portentously teasing way, will not tell us exactly what, but he hints that Mrs. Doyne had never fully appreciated her husband's genius, and now, in an "attitude of reparation, ${ }^{20}$ she hopes to make up for it by authorizing a multivolume biography of the great man-a life amply written as atonement for a life incompletely lived. She chooses for the job an acquaintance of his, a young writer named George Withermore, talented but still rising, who is dazzled by the offer. Mrs. Doyne is completely "free" to do as she likes in assigning the task of biography. All the materials of Doyne's life-his "diaries, letters, memoranda, notes, documents of many sorts-were her property 
and wholly in her control, no conditions at all attaching to any portion of her heritage." 21 Mrs. Doyne, as owner in fee simple of her husband's past, alone can authorize access to his buried life and supervise its excavation. Her choice of the obscure, malleable Withermore is calculated to maximize her control.

Given the run of the great man's study, Withermore sets to work every evening unlocking drawers and poring over papers, mysteriously aided, he feels, by Doyne's approving presence. When on occasion Withermore mislays a document, it suddenly turns up as if restored by an invisible hand. When he happens upon some of Doyne's "secrets" while "drawing many curtains, forcing many doors, reading many riddles," he senses that he has the blessing of the departed author, "his mystic assistant." For Withermore, the experience is "an intercourse closer than that of life."22 This unexpected intimacy with the obliging ghost leads him to look forward to "the growth of dusk very much as one of a pair of lovers might wait for the hour of their appointment." ${ }^{.33}$ Strangely, in this process of uncovering and assembling a life, both biographer and widow feel closer to Doyne than they did when he lived. The work of biography becomes both an active search for a personality taken for granted in life and a passive surrender to a subjectivity that is being painstakingly conjured from private documents.

Withermore's work moves along swiftly and satisfyingly for a time. Then something happens; the mood of spectral collaboration changes. He suddenly feels that Doyne has left him, that the phantom's approval has been withdrawn. Withermore recalls that in life Doyne had doubted the value of biography and had asserted that " $t]$ he artist was what he did-he was nothing else." 24 Awakened to the possible impropriety of his commission, the young man explains to Mrs. Doyne that "[t]here are natures, there are lives, that shrink" from public scrutiny. ${ }^{25}$ "He strains forward out of his darkness, he reaches toward us out of his mystery, he makes us dim signs out of his horror." The "horror," Withermore tells the startled widow, is the ghost's alarm "[a]t what we're doing." Doyne has given signs that he opposes a triple-decker monument. "He's there to be let alone." 26 At the end of the story, both Withermore and Mrs. Doyne "give up," convinced that Doyne's perturbed spirit has barred the way to biographical reparations. Though she had thought she was doing the right thing by commemorating her husband in gilt-edged detail, Mrs. Doyne realizes that she must do "the real right thing" by respecting his right to be let alone. ${ }^{27}$ The best life, it turns out, is the unrecorded life. ${ }^{28}$

James was preoccupied with the privacy of the dead. Earlier, in The Aspern Papers (1888), he had offered a portrait of the degraded deviousness to which an obsession with the secrets of a great writer could lead. The narrator of the novella, a writer himself, ingratiates himself with Juliana, an elderly woman who had once been the lover of the famous poet Jeffrey Aspern, and soon becomes a lodger in her decaying palazzo in Venice, all in order to be near a virgin cache of Aspern's letters. Carried away by lust for hidden knowledge, the narrator one night furtively rifles Juliana's desk, only to be caught in the act and branded by her a "publishing scoundrel."29 Later, on the brink of contracting a loveless marriage with Juliana's niece and heir-among the tale's morally perverse fungibilities is the narrator's readiness to exchange his ethical being for access to the unseen papers-it is only the niece's revelation that she has burned the papers "one by one" that restores the narrator to humiliated sobriety. ${ }^{30}$

In a different key, Morris Gedge in James's novella The Birthplace (1903) grows obsessed with a famous unnamed poet-obviously Shakespeare-after Gedge and his wife become custodians of the bard's much-visited birthplace. Distressed over tourists' uncritical voracity for rank legend, and desiring only "to let the author alone,"31 Gedge takes to prowling about at midnight and communing with the poet's spirit in the darkness of "the sublime Chamber of Birth."32

Nocturnal encounters with an elusive biographical subject in a small, sacred room are a regular ghostly motif in James's fictions, but none of his treatments brings together as succinctly as does "The Real Right Thing" the themes of privacy, unpublished documents, and literary property rights. The story's legal donnée is the widow Doyne's unchallenged ownership of these rights and her consequent ability to "control" all biographical revelations. She is "free to do as she liked-free in particular to do nothing." 33 As the inheritor of her husband's copyrights, she has stepped into his vacated sovereignty and assumed his power to bind and to loose, to publish or to withhold-the very prerogatives of the possessive authorial self.

In 1890 , nine years before James's tale of forbidden biography appeared, two Boston lawyers, Samuel D. Warren and Louis D. Brandeis, published in the Harvard Law Review a groundbreaking article entitled "The Right to Privacy." 34 In it, they argued that "the right to enjoy life" in the modern 
era must include "the right to be let alone." "The press," they wrote, "is overstepping in every direction the obvious bounds of propriety and of decency. Gossip is no longer the resource of the idle and the vicious, but has become a trade which is pursued with industry as well as effrontery .... The intensity and complexity of life attendant upon advancing civilization have rendered necessary some retreat from the world." 35 Warren and Brandeis argued that the common law should acknowledge the sacredness of human privacy by making violators liable for damages in tort. Existing causes of action for defamation or conversion could not get at the particular dignitary harm inflicted by an invasion of personal privacy. Today, a variety of privacy torts is recognized and enforced in almost all states ${ }^{36}$; the availability of a right to be let alone owes much to the pioneering efforts of these two moonlighting lawyers.

Warren and Brandeis reasoned that a right to privacy could be inferred from the intellectual property rights that are recognized in private, unpublished papers. "The principle," they wrote, "which protects personal writings and all other personal productions, not against theft and physical appropriation, but against publication in any form, is in reality not the principle of private property, but that of an inviolate personality." 37 The law's protection of unpublished documents was only superficially a concern for property; in truth, it was a chivalrous acknowledgment of the sacred space of individuality under threat from "the too enterprising press, the photographer, or the possessor of any other modern device for recording or reproducing scenes or sounds." 38 The law, in its fumbling, case-bound way, had pointed the way to the real right thing by recognizing perpetual rights in unpublished writings. ${ }^{39}$

The widow Doyne likewise bases her power over her husband's private life on her ownership of the rights in his papers. But the great irony is that her unassailable property right does not, in the end, allow her to divulge her husband's secrets--.he continues to hold a veto power from the grave. Doyne, though defunct, remains stronger than the bundle of rights that the law recognizes in the unpublished witnesses to his earthly existence. Warren and Brandeis had contended for a privacy right of living persons, and today in the United States the right of privacy is largely confined to the living (though some states now recognize publicity rights for deceased personalities). ${ }^{40}$ James took the matter much further by writing an amicus brief for the right of the dead to be let alone. And yet Doyne's postmortem resistance, his determination to haunt his widow's commemorative enterprise, is consistent with Warren and Brandeis's claim that literary rights in unpublished documents are only an outward and visible sign of the larger sacrality of personality. Personality, like its crude signifier, the ghost, can be thought of as surviving death and transcending a mere right to damages. In "The Real Right Thing," James makes just that argument by closing the story with the ghost triumphant in his preserved privacy.

By linking the duration of protection to a term of years running from the authors' death - a property right post mortem auctoris - copyright law has invited a lugubrious rhetoric of commemoration, a musty, dead-flower discourse in which legal protection is often equated with respectful mourning for defunct authors and the public domain is stigmatized as a brazen desecration of their memory. As Paul K. Saint-Amour has urged,

\begin{abstract}
A hauntological reading of copyright should address the frequent appearance of ghosts, vampires, revenants, and the undead in the figurative discourses-both critical and celebratory--surrounding literary property law. But it must go on to tie that figural repertoire into the categories and deep structures of the law, asking how the spectral operations of haunting, oblation, exorcism, consecration, and contamination might speak to the socioeconomic and cultural work of copyright law. Such a reading should also see the ways the law constructs, polices, and sometimes breaches the border between the living and the dead as symptomatic of its manipulations of other categories, other thresholds. ${ }^{41}$
\end{abstract}

Fair use, that fore-glimpse of the unstinted public domain, has been accused of being a failed mourner, even a grave-robber. The late Jack Valenti, former CEO and president of the Motion Picture Association of America, denied the legal existence of fair use, as if the doctrine itself were a kind of posing ghost: "Now, fair use is not in the law. People are taking fair use and changing it to unfair use and claiming that it's fair use." ${ }^{342}$ When the attorney for a major publisher informed the estate of James Joyce, which had opposed Professor Carol Loeb Shloss's scholarly biography of Joyce's daughter Lucia, that the publisher considered Shloss's quotations from Joyce family papers to be privileged by fair use, Joyce's grandson, Stephen Joyce, replied that the publisher's fair use claim "sounds like a bad joke or wishful thinking." 43 The estate's opposition was grounded in its oft-averred commitment to protecting the privacy of James 
Joyce and members of his family, living and dead. As Stephen Joyce bluntly told a New Yorker interviewer, the Joyces' private life is "'no one's fucking business." ${ }^{34}$

At the center of the estate's resistance to biographical inquiry are the many letters by Joyce and his family that remain unpublished. This resistance has taken the form of destruction of documents, authorized removal of letters from a public archive, and frequent denials of copyright permission and threats of legal reprisal. ${ }^{45}$ Stephen Joyce once stated that he had stood beside his grandfather's grave in Zürich and received approval of his plan to speak his mind, uninvited, at an event commemorating his grandfather in London. ${ }^{46} \mathrm{Mr}$. Joyce is an embodiment of Henry James's ideal of protecting the author in "the tower of art, the invulnerable granite," free from the taint of revealed secrets and meddling biographers-except that in "The Real Right Thing," Doyne's ghost, the "pale forewarned victim," ${ }^{47}$ overrules the commemorative designs of his widow, whereas James Joyce has never been known to disagree with his grandson. The understanding between Joyce's spirit and its earthly agent would appear to be complete.

A hauntological reading of fair use must begin by grappling with the elusive ghost of privacy. The reverential treatment accorded to unpublished works by courts and publishers has deep roots in the pre-1978 distinction between common law copyrights and federal copyrights. Under the 1909 U.S. Copyright Act, federal protection began when a work was published with a proper copyright notice. Up to that point, the work enjoyed protection under state law, known as common law copyright. In contrast to federal law, which confined protection to a term of years and permitted fair use of published works, common law copyright could last forever, or as long as a work remained unpublished, and forbade most uses of the work, including fair use. ${ }^{48}$ Citing Warren and Brandeis's article, the U.S. Supreme Court once observed that "common-law copyright was often enlisted in the service of personal privacy."49 Authorial privacy was virtually guaranteed under state law. Unlike a federally protected published work, an unpublished work did not have the character of a public good, but rather was more like chattel, safeguarded by an absolute prohibition on theft as long as the proprietor chose to withhold the work from the public. Under this regime, an unpublished work was synonymous with privacy.
A landmark case addressing fair use of unpublished works under the 1976 Act was Harper \& Row $v$. Nation Enterprises, in which the Supreme Court in 1985 was asked to decide whether The Nation magazine had infringed the copyright in former President Gerald Ford's unpublished memoirs by printing brief, unauthorized excerpts prior to the planned, authorized publication of an extract in Time magazine. The Nation's act of scooping Time was governed by federal law-the 1976 Act had eliminated common law copyright, for all relevant purposes-so the question for the Court was how far the fair use doctrine extended to federally protected unpublished works, and whether The Nation had made fair use of Ford's memoirs. A majority of the Court concluded that The Nation, though it had quoted only 300 words from the 200,000-word manuscript, was an infringer because "the scope of fair use is narrower with respect to unpublished works" and The Nation had reproduced the qualitative "heart" of the memoirs—Ford's account of his pardon of Richard Nixon." "A use that so clearly infringes the copyright holder's interests in confidentiality and creative control is difficult to characterize as "fair."'51

In a feisty dissent, Justice Brennan rejected the majority's characterization of the memoirs as confidential, pointing out that they were about to be published for commercial gain when The Nation scooped Time. "What the Court depicts as the copyright owner's 'confidentiality' interest," he wrote, "is not a privacy interest at all. Rather, it is no more than an economic interest in capturing the full value of initial release of information to the public." ${ }^{12}$ The majority, Brennan argued, had given the unpublished nature of the memoirs conclusive priority, without properly inquiring into the actual or potential harm of The Nation's prepublication use. ${ }^{53}$ This priority, he suggested, had been conceded out of uncritical respect for the privacy of an author's unpublished thoughts, a remnant and revenant of pre-1976 law.

The Court, Brennan worried, was introducing "a categorical presumption against prepublication fair use." 54 That fear was realized two years later in another case, Salinger $v$. Random House, Inc., when the Second Circuit reversed a trial court's denial of a preliminary injunction to J. D. Salinger. Salinger had sought to enjoin the distribution of an unauthorized account of his life on the theory that the biographer had infringed the reclusive author's copyrights in his unpublished personal letters, even though the original letters were available to the public in university libraries. Sensing the real purpose of Salinger's lawsuit, the trial court found fair 
use: "[The biography] cannot be dismissed as an act of commercial voyeurism or snooping into a private being's private life for commercial gain. It is a serious, well-researched history of a man who through his own literary accomplishments has become a figure of enormous public interest." $" 55$

The Second Circuit reversed, noting that the Supreme Court in Harper $\&$ Row had "underscored the idea that unpublished letters normally enjoy insulation from fair use copying." on the unpublished nature of Salinger's letters, the court mostly avoided discussing the author's privacy motive. But commentators were quick to point to "the court's tacit agenda: protection of Salinger's privacy." Pierre Leval, the judge who had ruled in favor of Salinger's biographer in the trial court, wrote afterwards, "Serious distortions will occur if we permit our copyright law to be twisted into the service of privacy interests." 58

A related poltergeist that rattles the cupboards of fair use is the author's right of first publication. The Supreme Court in Harper \& Row described this right, carried over from the common law, as giving the author the exclusive choice "whether and in what form to release his work" and as involving "not only his personal interest in creative control but his property interest in exploitation of prepublication rights." ${ }^{159}$ Although the attorneys for The Nation had argued, sensibly, that the first-publication right was none other than the exclusive right of public distribution, which, equally with the other exclusive rights listed in Section 106, is limited by the fair use privilege under Section 107, the Court rejoined that the distribution right was "inherently different from other $\$ 106$ rights in that only one person can be the first publisher." "Under ordinary circumstances," the Court announced, "the author's right to control the first public appearance of his undisseminated expression will outweigh a claim of fair use." unnuanced statement would be picked up and deployed as a flat rule by the Salinger panel. ${ }^{61}$

Like inordinate sensitivity for privacy, reverence for the right of first publication must be exorcised as a conclusive factor in fair use analyses. As scholars have noted, elevation of the first-publication right in Harper \& Row and Salinger was a strategy for importing protection for privacy and authors' moral rights. ${ }^{62}$ One of the traditional European moral rights is Le droit de divulgation: the exclusive right to choose where, when, and whether to publish. U.S. copyright law has largely avoided adopting moral rights, ${ }^{63}$ yet American publishers are still haunted by the sensational facts and solicitous holdings of Harper \& Row and Salinger, cases that involved piratical scooping by a magazine and the morbid reclusiveness of a famous living author. Hard cases should not drive a doctrine as important as fair use. That is why Congress in 1992 amended Section 107 "to roll back [Salinger's] virtual per se rule" for unpublished works. ${ }^{64}$

Ghosts sometimes remind us of their power through inconspicuous hauntings. In November 2010, HarperCollins Publishers-descendant by corporate merger of Harper \& Row-sued the blog network Gawker Media ("Today's gossip is tomorrow's news") for posting on its website, without authorization, twenty-one pages from Sarah Palin's America by Heart: Reflections on Family, Faith, and Flag, several days before the volume was scheduled to appear in bookstores. The excerpt contained Palin's criticisms of various public figures, including John F. Kennedy, the Obamas, and the Obamas' former pastor Jeremiah Wright. After receiving a demand letter from HarperCollins, Gawker reduced its original post to portions of twelve pages from Palin's book, but the publisher persisted in its request for a temporary restraining order. After an expedited hearing, the U.S. District Court for the Southern District of New York issued the order, finding that HarperCollins was likely to defeat Gawker's fair use defense at a full trial. Gawker's use, said the court, was essentially a commercial one that lacked sufficient transformative commentary or discussion. As for the second fair use factor, the court stated flatly, "[T]he excerpts used by defendant come from an unpublished work, substantially weakening defendant's fair use claim. See Harper E Row, $47 \mathrm{I}$ U.S. at $564 . " 65$ End of analysis. No reference to the 1992 amendment by which Congress had attempted to banish a dangerous per se rule. HarperCollins, like its famous predecessor Harper \& Row, leaves us with few certainties about the present or future of fair use, except one: there is something about unpublished works that continues to shock and awe courts. The ghost still walks.

\section{$* * *$}

Henry James was wrong. He was a privacy fanatic who worried that the tower of art would be toppled by revelations about authors' lives. Courts, publishers, and scholars should resist the message of "The Real Right 
Thing." Unlike J. D. Salinger, Ashton Doyne was dead when he set his ghostly face against biography. Unlike The Nation, George Withermore had no intention of scooping an authorized publication. James's story involves a much more common scenario for historians, biographers, and critics: the need to quote from a deceased person's unpublished writings to which physical access has been granted (usually through archives) but which remain otherwise shielded by a force from beyond the grave. Yet this ghostly force, as James figures it, is not entirely menacing: there is the moment of intimacy when Withermore feels drawn to his biographical subject like an excited lover, when in "the narrow passage and tight squeeze of the past" he senses that he and Doyne are "really for the first time together." ${ }^{366}$ Here, despite the dogmatic tenor of his tale, James fleetingly concedes the cost of fetishizing the privacy of the dead. For just this moment, James allows himself to imagine the transtemporal effect that an intimate biographical project might allow to pass between the living and the dead, even as the prospect of such a tender transaction offends his sense of privacy. ${ }^{67}$ What is tragically cancelled by James's privacy fanaticism is the possibility that granting access to a dead author's expression might open the way for a new kind of ghostly transgenerational congress, a productive collaboration between past and present that could transcend the widow Doyne's myopic goal of making amends for her wifely derelictions-a haunting with a difference.

In the end, James could not fully admit the transformative fruitfulness of such collaborations. His fear was too great that the biographer and his subject would be surprised in their trysting place by an insensitive public bent upon scandal and sensation. And so he buried his collaborative insight in a passage depicting Withermore's youthful optimism, and built the rest of the story around Doyne's moral appeal for privacy. Today, that appeal is felt as exaggerated solicitude on the part of courts and publishers for unpublished works. But where an author is deceased, privacy concerns should be at a minimum, as they are in other areas of American law; moral qualms about divulgation should seem less keen when the author is departed and there is only an heir or transferee to invoke, by a kind of suspect ventriloquism, a personal right of first publication. The case for fair use should be even clearer when unpublished documents are available for unrestricted inspection in archives open to the public. Again, I am not suggesting that fair use of unpublished works should be confined to situations in which the author is deceased; in my view, privacy and moral rights are interlopers in all fair use analyses, except perhaps in unusual instances at the margin. Cases involving dead authors are simply a good place to begin the analytical work of exorcism.

It is precisely when the ghost of Ashton Doyne rises up in the form of vestigial, Salinger-like conceptions of fair use that Congress's 1992 amendment has most force. That obsessed phantom, rattling the chains of privacy and moral rights, has no place in a proper weighing of fair use factors. We should retire its distracting visitations in favor of the ironic uncanniness of transformative fair use-a quality exhibited in much scholarly work. Once Doyne's ghost is laid by courts and gatekeepers, the future of the fair use doctrine will be brighter, and copyright law in the United States will better serve the constitutional purpose of advancing the progress of learning.

17 U.S.C. $\$ 107$.

2. Campbell v. Acuff-Rose Music, Inc., 510 U.S. $569, \$ 79$ (1994).

3. Blanch v. Koons, 467 F.3d 244 (2d Cir. 2006).

4. Sigmund Freud, "The Uncanny," in Collected Papers, vol. 4, trans. Joan Riviere (New York: Basic Books, 1959), 403.

5. 471 U.S. $539(1985)$

6. 8II F.2d 90 (2d Cir. 1987).

7. Id. at 97 .

8. New Era Publ'ns Int'l v. Henry Hole \& Co., 873 F.2d 576,583 (2d Cir. 1989) (discussing unauthorized use of unpublished writings in biography of $L$. Ron Hubbard) (dictum).

9. See, e.g., Vincent H. Peppe, "Fair Use of Unpublished Materials in the Second Circuit: Letrers of the Law, Salinger v. Random House, Inc.," ${ }_{4} 4$ Brooklyn Law Review 417, 425 (1988) ("[T]he Second Circuit's overemphasis of the unpublished nature of a biographical subject's letters were [sic] an improper attempt to apply the protections of copyright law to personal privacy"); see also Kate O'Neill, "Copyright Law and the Management of J. D. Salinger's Literary Estate," 31 Cardozo Arts E Entertainment Lay Joumal 19, 19-44 (2012) (offering a sustained critique of judicial treatment of authorial privacy and moral rights in the Salinger lawsuits and other cases).

10. After Salinger, attorneys for American publishers stated that they would now advise their clients to be very cautious about quotations from unpublished works (Peppe, supra note 9, at $460-61$ \& n.274).

Ix. 17 U.S.C. $\$ 107$.

12. For judicial trends up to 1998, see Robert Spoo, "Fair Use of Unpublished Works: Scholarly Research and Copyright Case Law Since 1992," 34 Tulsa Law Joumal 183, 183-200 (I998). Since 1998, relevant fair use findings have included Vanderhye v. iParadigms $L L C, 562 \mathrm{~F} .3 \mathrm{~d} 630$ (4th Cir. 2009) (holding that copying of students' unpublished essays by plagiarism-detecting technology was fair use), and Bond v. Blum, 317 F.3d 385 (4th Cir. 2003) (concluding that introducing copy of ex-husband's unpublished autobiographical "manuscript as relevant evidence in custody trial was 
fair use). The decision that comes closest to the concerns of this essay is Sundeman v. Seajay Society, Inc., 142 F.3d 194 (4th Cir. 1998), which found transformative fair use where a scholar quoted from an unpublished Marjorie Rawlings novel in an oral presentation at a scholarly symposium. The court hinted, however, that had the scholar published the talk, "potential commercial motivation" might have altered the court's analysis. Id. at 203.

13. I serve as copyright advisor to the Joumal of Modem Literature, Twentieth Century Literature, the James Joyce Quarterly, and other academic journals and projects. Editors frequently express concern Jout the legal consequences of unauhorized quotation of unpublished sources, even when quotation is brief and embedded within transformative scholarship. At a conference entitled " The Quote's the Thing': Negotiating Copyright in Scholarly Criticism," held at the University at Buffalo in April 201r, Peter J. Potter, Editor in Chief at Cornell University Press, spoke of continuing worry at academic presses over their authors' use of copyrighted materials that are unpublished.

14. For a discussion of copyright gatekeepers, see Peter Decherney's essay in this issue.

15. See Kate O'Neill, “Against Dicta: A Legal Method for Rescuing Fair Use from the Right of First Publication," 89 Califomia Law Review 369, 394-97 (2001), for a critique of publishers' word-coun policies and strict author contracts.

16. Robert Spoo, "Copyrights and 'Design-Around' Scholarship," 44 James Joyce Quarterly $563-85$ (2007)

17. 17 U.S.C. $\mathbb{S S} 201,302-305$

18. Kiraly v. FBI, 728 F.2d 273, 280 (6th Cir. 1984) ("A dead man retains no right to privacy after his death") (citations omitted); U.S. v. Amalgemated Life Ins. Co., 534 F. Supp. 676, 679 (S.D.N.Y. I982) ("The right to privacy ... terminates upon death and does not descend to the heirs of the deceased") (citing cases).

19. See Leon Edel, Henry James: A Life (New York: Harper \& Row, 1985), 664

20. Henry James, "The Real Right Thing," in The Novels and Tales of Henry James, vol. XVII (New York: Charles Scribner's Sons, 1909), 411 .

21. James, $i d$. at $411-12$.

22. $I d$. at 420,422

23. Id. at 419 .

24. Id. at 415 .

25. Id. at $427-28$.

26. Id. at 428 .

27. Id. at 426 .

28. For a discussion of "The Real Right Thing" that touches on international copyright and literary property, see Amy Tucker, The Illustration of the Master: Henry James and the Magazine Revolution (Stanford CA: Stanford University Press, 2010), 55-56.

29. Henry James, The Aspem Papers, in The Novels and Tales of Henry James, vol. XII (New York: Charles Scribner's Sons, 1909), 118

30. Id, at $142-43$.

31. Henry James, The Birthplace, in The Novels and Tales of Henry James, vol. XVII (New York: Charles Scribner's Sons, 1909), 180

32. Id. at 153 .

33. James, supra note 20 , at $4 \mathrm{I2}$.

34. For an excellent use of Warren and Brandeis' article to shed light on James's fictions of private life, see Richard Salmon, "'The insurmountable desire to know': Privacy, Biography and 'The Aspen Papers,"' in Henry James and the Culture of Publicity (Cambridge: Cambridge University Press, 1997), 77-115. A rich discussion of Warren and Brandeis in connection with James's complex attitudes toward privacy as registered in The Aspern Papers and other fictions is found in Brook
Thornas, "Henry James and the Construction of Privacy," in American Literary Realism and the Failed Promise of Contract (Berkeley: University of California Press, 1997), $53-87$.

35. Samuel D. Warren \& Louis. D. Brandeis, "The Right to Privacy, ${ }_{4}$ Harvard Law Review 193,196 (1890).

36. Paul M. Schwartz \& Karl-Nikolaus Peifer, "Prosser's Privacy and the German Right of Personality: Are Four Privacy Torts Berter than One Unitary Concept?" 98 California Law Review 1925, 1940 (2010).

37. Warren \& Brandeis, supra note 35, at 205.

38. $I d$. at 206 .

39. Salmon's discussion of Warren and Brandeis's article is helpful on these points; Salmon, supra note 34 , at $82-83$.

40. Pierre N. Leval, "Toward a Fair Use Standard," I03 Harvard Law Review n105, 1116-22, 1130 (1990); see also Jessica Bozarth, "Copyrights and Creditors: What Will be Left of the King of Pop's Legacy?", Note, 29 Cardozo Ars \& Entertainment Law Journal 85, 100-101 (2011) (noting that nineteen states recognize some form of descendible publicity rights).

41. Paul K. Saint-Amour, The Copywrights: Intellectual Property and the Literary Imagination (Ithaca NY: Cornell Universiry Press, 2003), 130-31. The title of the present essay is a response to chapter 4 of this important study ("The Reign of the Dead: Hauntologies of Postmortem Copyright"), 121- 58.

42. "Interview: Jack Valenti" (Nov. 14, 2003), Darknet: Hollywood's War against the Digital Generation, at hatp://www.darknet.com/2005/06/interview jack htol (accessed December 2012)).

43. Stephen Joyce to Leon Friedman (November 21, 2002), quoted in Amended Complaink for Declaratory Judgment and Injunctive Relief, Shloss $\nu$. Sweeney, Case No. CV o6-3718, at to (N.D. Cal. filed October 25, 2006). I was one of the attorneys who represented Shloss in her lawsuit against the Joyce estate and Stephen Joyce.

44. Quoted in D. T. Max, "The Injustice Collector: is James Joyce's Grandson Suppressing Scholarship?" The New Yorker (june 19,2006$), 36$.

45. See, e.g., Caryn James, "Joyce Family Letters in Literary Debate," New York Times (Aug. I\%, 1988), 13, 15 ; Max, supra note 44, at 35-36; Spoo, supra note 16; at $565-68$; Robert Spoo, "Three Myths for Aging Copyrights: Tithonus, Dorian Gray, Ulysses," 31 Cardozo Arts \& Entertainment Law Journal 77, 80-109 (2012)

46. "Stephen Joyce: Protective grandson who refuses to Rejoyce," Sunday Times (Dublin ed.) (Feb. I5, 2004); see also Max, supra note 44, at 39 ("Even now, when Stephen has to make important decisions about the estate, he sometimes goes to Joyce's grave to consult with him.").

47. These phrases are taken from James's essay on George Sand's personal letters, "She and He: Recent Documents," The Yellow Book: An Illustrated Quarterly 22, 22-23 (Jan. 1897).

48. Stanley v. Columbia Broad. Sys., 221 P.2d 73, 78 (Cal. 1950); see also Peppe, supra note 9, at 4.23 \& n. 37 (discussing common law copyright's treatment of fair use)

49. Harper Row, $47 \mathrm{I}$ U.S. at 554 .

5o. Id. at $564-6 \xi$.

I. Id. at 504

52. Id. at $597-98$ (Brennan, $\mathrm{J}$., dissenting)

53. Id. at 598 (Brennan, J., dissenting).

54. Id. at 595 (Brennan, J., dissenting).

55. Salinger y. Random House, Inc., 650 F. Supp. 413, 426 (S.D.N.Y. 1986), rev'd, 811 F.2d 90 (2d Cir. 1987).

Salinger, 8 II F.2d at 95

57. Peppe, supra note 9, at 458; see also Wright v. Warner Books, Inc., 748 F. Supp. 105, 110 (S.D.N.Y. 1991) ("[W] hat motivated the Court of Appeals in Salinger, at least in part, was concern over ]. D. 


\section{Law \& Literature - Volume 25, Number}

Salinger's right to privacy."), affd, 993 F.2d 73x (2d Cir. 1991); Diane Leenheer Zimmerman, "Information as Speech, Information as Goods: Some Thoughts on Marketplaces and the Bill of Rights," 33 William \& Mary Law Review, 665, 672 (1992) ("The property really at issue in Salinger was his privacy, his claimed right to control the public dissemination of information about his life and attitudes.").

58. Leval, supra note 40 , at 1330

59. Harper \& Row, 471 U.S. at 553, 555 .

6o. Id. at 555 .

61. See Salinger, 811 F.2d at 95. For a recent discussion of Salinger, privacy, and the right of first publication, see Daniel Pecchenino, "If You Want to Know the Truth': Fair Use, Authenticiry, and J. D. Salinger," 83 American Literature 579-619 (2011).

62. See, e.g., Diane Conley, "Author, User, Scholar, Thief: Fair Use and Unpublished Works," Cardoz̧o Arts \& Entertainment Law Joumal 15, 31-33 (1990).

63. Federally protected moral rights exist for certain works of visual arts. 17 U.S.C. \$ 106A.

64. "Copyright Legislation in the rozd Congress," 40 Journal of the Copyright Society of the U.S.A. I 123 (1992) (statement of Senator Leahy).

69. HarperCollins Publishers, L.L.C. v. Gawker Media L.L.C., 721 F. Supp. 2d 303, 306 (S.D.N.Y. 2010)

66. James, supre note 20 , at 416,420 .

67. Compare Carolyn Dinshaw's project of causing past and present to meet in a mutually disorienting moment of recognized difference, a project she figures, after Roland Barthes, as the work of "a queer historical touch" and a "desire for bodies to touch across time." Dinshaw, Getting Medieval. Sexualities and Communities, Pre- and Postmodern (Durham NC: Duke University Press, 1999), 3. 